\title{
Infected Seymour-Type Fracture
}

\section{Fratura Seymour-Type Infetada}

Pedro Martins Brancoํㅡ, Carolina Baptista², Carlos Maia Dias, Gonçalo Martinho1, Manuel Oliveira¹, António Júlio Silva ${ }^{1}$

\begin{abstract}
Extra-articular, transverse, distal phalangeal fractures that involve the physis, are termed Seymour fractures. They are frequently associated with an avulsion of the nail and a laceration of the nail bed. For this type of fractures, surgical intervention is needed to explore the fracture site for soft tissue interposition. Its failure may result in several complications. The authors report an adult Seymour-type fracture, which developed an infection due to interposition of the germinal matrix of the nail complex on the fracture site. The purposes of this article are to demonstrate that this rare fracture can also occur in adults, highlight the importance of treating this injury with the basic principles of open fracture treatment, and evidence one of its complications if not well treated.
\end{abstract}

KEYWORDS: Finger Injuries/surgery; Finger Phalanges/injuries; Fractures, Open

\section{RESUMO}

Fraturas extra-articulares, transversais, da falange distal que atingem a fise, são chamadas fraturas de Seymour. Estão geralmente associadas a avulsão da unha e a laceração do leito ungueal. Neste tipo de fraturas, o tratamento cirúrgico é necessário para averiguar se existe interposição de partes moles no foco de fratura. Se isto não for feito, podem decorrer várias complicações. Os autores apresentam o caso clínico de uma fratura Seymour-type em idade adulta, que desenvolveu uma infeção devido à interposição da matriz germinal do complexo ungueal no foco da fratura. Os objetivos do presente artigo são demonstrar que esta fratura rara também pode ocorrer em idade adulta, salientando a importância do tratamento desta lesão segundo os princípios básicos do tratamento das fraturas expostas, e evidenciar uma das suas complicações se não for corretamente tratada.

PALAVRAS-CHAVE: Falanges dos Dedos da Mão/lesões; Fraturas Expostas; Lesões dos Dedos/cirurgia 


\section{INTRODUCTION}

Extra-articular, transverse, distal phalangeal fractures that involve the physis ${ }^{1}$ are termed Seymour fractures. ${ }^{2}$ In the literature there are only few articles about fractures of adulthood mimicking Seymour fractures. ${ }^{1,3}$

In this type of fractures, the nailbed and germinal matrix may be lacerated and become entrapped in the fracture site. ${ }^{4}$ In these cases, surgical intervention is needed to explore the fracture site for soft tissue interposition and to obtain anatomical alignment and fixation of the fracture. Its failure may result in several complications. ${ }^{5}$

This paper reports on a patient with a Seymour-type fracture, who developed an infection after closed reduction and internal fixation with Kirschner wires, and no antibiotics prescription. To our knowledge, this complication is not described associated with a Seymour-type fracture in the literature.

The purpose of this article is to demonstrate that this rare fracture can also occur in adults, to highlight the importance of treating this potentially benign-appearing injury with the basic principles of open fractures, and to demonstrate its complications if not well treated.

\section{CASE REPORT}

A 23-year-old female patient was admitted to an Emergency Department with an incised wound on the dorsal side of the distal extremity of the middle finger of the left hand. The trauma occurred by the entrapment of the phalanx in a machine. Clinically, the injured digit presented with a mallet deformity, and a $5 \mathrm{~mm}$ incised wound, which extended proximally from the eponychial fold. The nail plate was subluxated, lying superficial to the eponychial fold.

Radiography showed an extra-articular, transverse fracture, localized at the metaphyseal region of the distal phalanx of the middle finger, just distal to the insertion of the extensor tendon (Fig. 1).

The patient was admitted on the operating room for surgical treatment at the same day of the trauma. The fracture was submitted to closed reduction and two crossed K-wires fixation (Fig. 2), and the wound sutured. Dressings were made, and a splint applied. The overlying wound had not been thoroughly irrigated and debrided and no antibiotics had been prescribed. The K-wires and the splint were removed four weeks after the trauma.

The patient presented to our Institution 5 weeks after injury, with swelling, redness and pus draining from the eponychial fold. The nail plate was partially avulsed, and

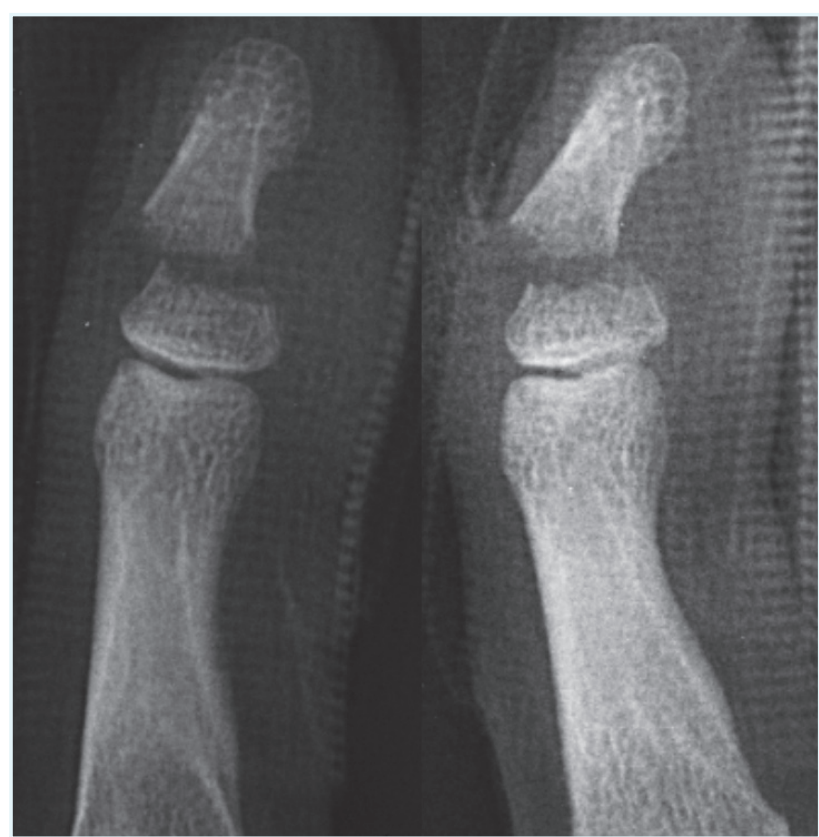

FIGURE 1. Typical radiographs of a Seymour-like fracture, demonstrating characteristic flexion deformity at the fracture site due to the overpull of the flexor digitorum profundus tendon.

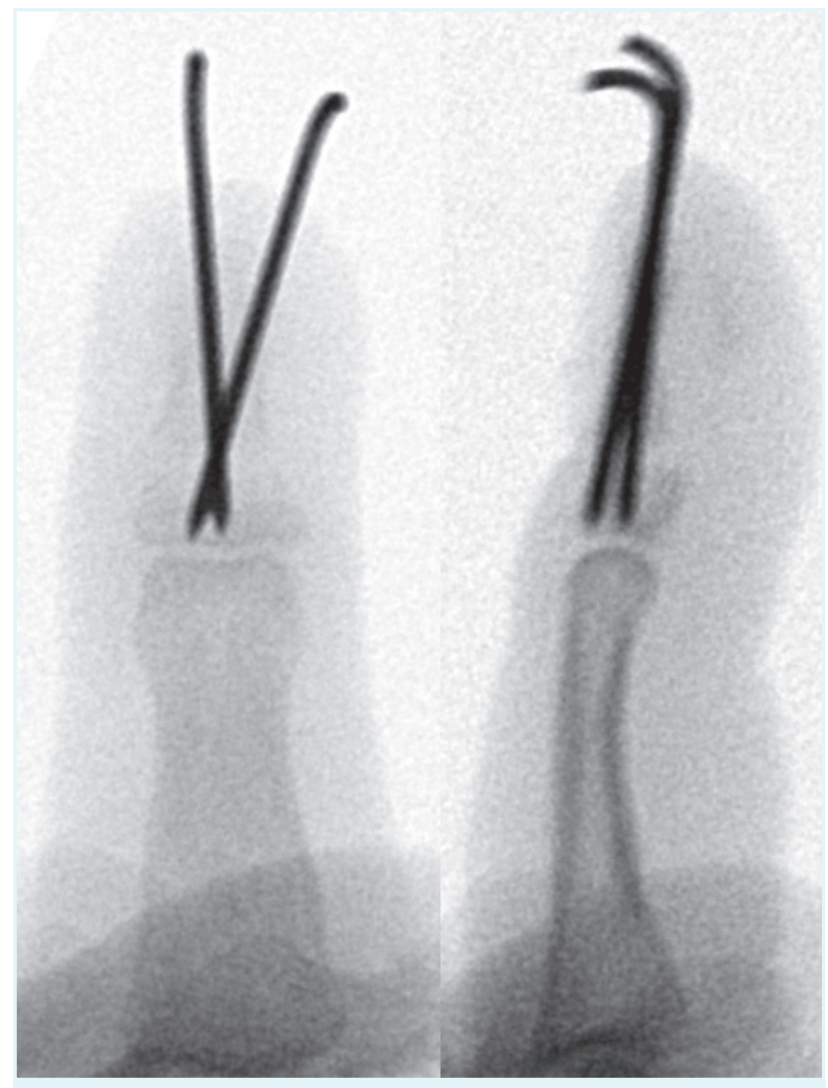

FIGURE 2. Intraoperative radiograph following closed reduction and two crossed K-wires fixation.

the finger had a mallet deformity appearance. Radiographies revealed the fracture and cultures taken grew Staphylococcus aureus, sensible to amoxicillin and clavulanic acid, prescribed empirically at the admission day in our Institution. Sonography excluded tendon injuries. 


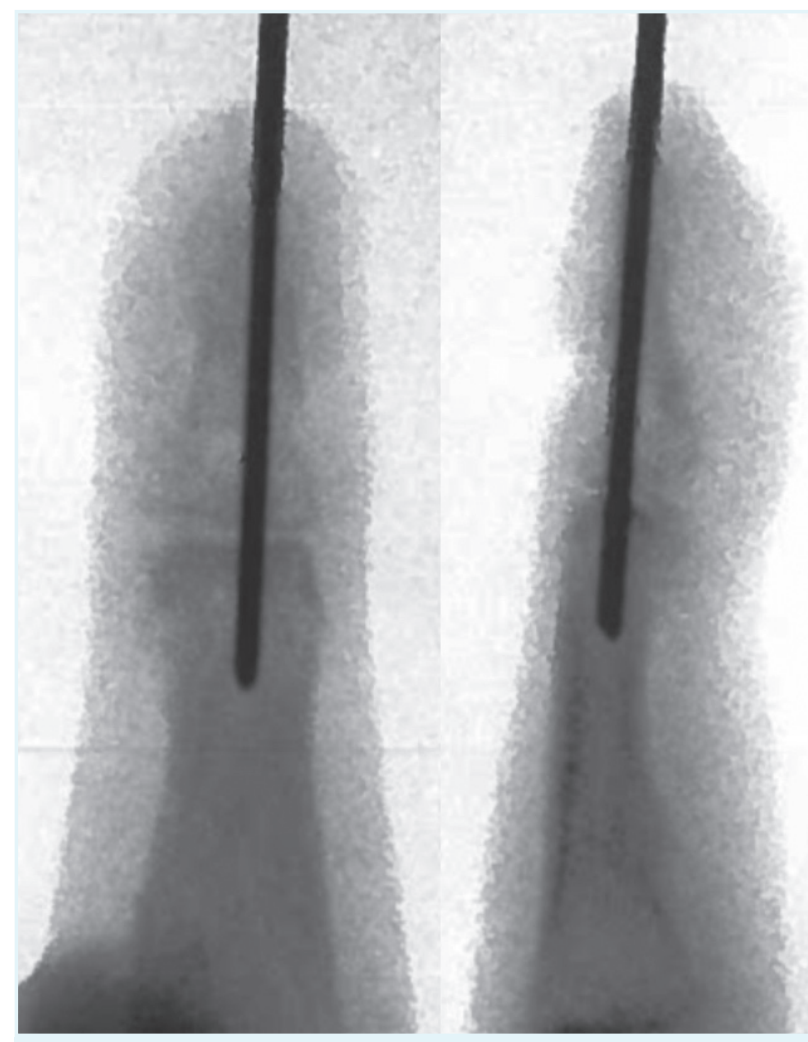

FIGURE 3. Intraoperative radiograph following soft tissue excision from the fracture site, anatomic open reduction of the distal fragment, and fixation with a K-wire across de distal interphalangeal joint.

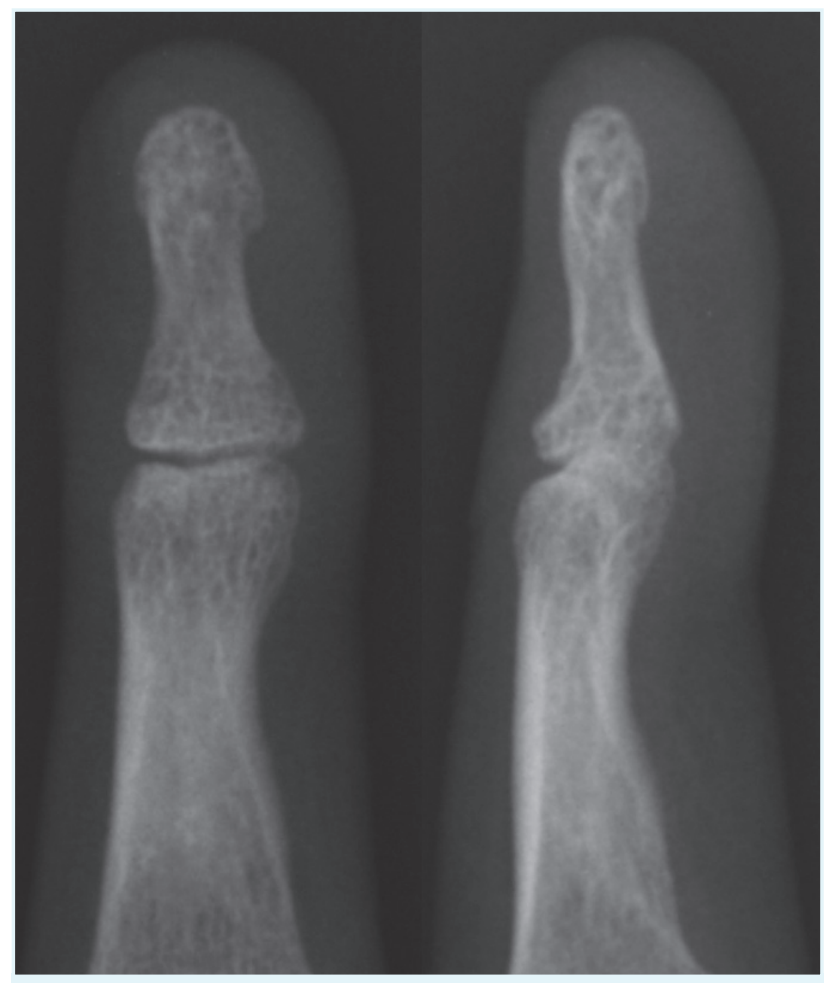

FIGURE 4. Radiographs 3 months postoperatively, demonstrating stable osseous union.
Seven weeks after the trauma, the patient was submitted to surgical treatment in our Institution. Nail plate removal, irrigation, and debridement were first performed. A small flap of soft tissue was interposed at the fracture site and was excised. Anatomic open reduction of the distal fragment, and fixation with a K-wire across de distal interphalangeal joint were performed (Fig. 3). The nailbed was repaired, and nail plate replaced under de eponychial fold. The injured finger was placed in an extension splint. The operation was performed by two senior surgeons. Oral antibiotic was kept.

Two weeks post-operatively the signs of infection had resolved, there was no evidence of infection on analytic evaluation, so the antibiotics were discontinued.

Four weeks after the procedure, the K-wire was removed and the splint discontinued. The proximal and distal interphalangeal joints revealed some restriction, so an exercise program was planned for the patient. She performed rehabilitation for 2 months after this surgery. The patient returned to daily activities 1 month after the surgery, and 2 months to full activity, including work.

Stable osseous union was confirmed on radiographs at 3 months (Fig. 4).

At the two and a half-year follow-up evaluation, the interphalangeal joints of the finger had re-established full motion. The patient did not complain about pain (VAS 0). QuickDASH score was 2.3. There was a slight nail growth disturbance - narrowing of the growth plate and partial onycholysis accentuated at the radial side (Fig. 5) - and rotation of the distal phalanx (Fig. 6). No further complications were registered, and no revision surgery was necessary.

\section{DISCUSSION}

Extra-articular, transverse, distal phalangeal fractures that involve the physis ${ }^{1}$ are termed Seymour fractures. ${ }^{2}$ There are no prevalence of gender, ${ }^{1,3}$ and this type of fractures typically involve a crushing type mechanism. ${ }^{6}$ They are usually open injuries with nailbed lacerations. ${ }^{3}$

Seymour ${ }^{7}$ was the first to emphasize this type of fracture in children. In the literature there are only few articles about fractures of adulthood mimicking Seymour fractures. ${ }^{1,3}$ Because of its similarities, we prefer to define them as Seymour-type fractures.

Because the terminal extensor tendon inserts into the epiphysis and the flexor digitorum profundus tendon inserts into the metaphysis, ${ }^{8}$ Seymour fractures typically result in a flexed posture of the distal phalanx, ${ }^{2,8}$ mimicking a mallet finger. ${ }^{1,8,9}$ 
Seymour's original description of the fracture did not specifically comment on the presence or absence of nailbed injury. ${ }^{10}$ The proximity of the displaced fracture to the nailbed frequently creates an associated injury near the germinal matrix, ${ }^{1,4}$ which may become entrapped in the fracture site, thereby preventing a closed reduction, ${ }^{4}$ as we observed in our case. Because a laceration is associated with the fracture, ${ }^{5}$ these are open fractures. . $^{1,5} 8$

Plain radiographs may appear normal in the posteroanterior plane, but the lateral view will demonstrate widening and/or significant displacement between the epiphysis and the metaphysis. ${ }^{5}$

Seymour fractures can be managed conservatively or with surgery, depending on the nailbed injury, reduction of the fracture site, and stability of the fracture. Some stable fractures can be treated conservatively. Although, patients with nailbed laceration and unstable fractures must be treated as open injuries. ${ }^{1}$ For this type of fractures, surgical intervention is needed to explore the fracture site for soft tissue interposition and to obtain anatomical alignment and fixation of the fracture. Its failure may result in nailplate deformity, physeal arrest, chronic osteomyelitis, ${ }^{5}$ and/or delayed union.

Seymour ${ }^{7}$ did not use intraoperative or postoperative antibiotics on his patients. In our opinion, open injuries are prone to infection and should be treated according to the treatment protocol for open fractures, including thorough irrigation, debridement and antibiotics.

The surgical procedure begins by removing the nailplate. A transverse laceration is usually present in the germinal matrix, which can be utilized to access the fracture site. Often, the germinal matrix tissue is found interposed in the fracture site and must be extracted. Once the germinal matrix tissue is removed, a thorough irrigation and debridement is performed. In cases of instability, it may be advantageous to apply a K-wire under fluoroscopic guidance through the distal phalanx and the distal interphalangeal joint. $^{2}$

Seymour fracture is an often-underestimated injury that can lead to many complications unless treated adequately. There are some complications described on the literature, like: incomplete reduction, fracture instability, residual pseudo-mallet deformity, infection, premature closure and dorsal rotation of the epiphysis, ${ }^{8}$ and nail growth deformity. ${ }^{1}$ In our case, the fracture evolved into an infection.

In Seymour fractures there is almost always a transverse laceration of the nail matrix. ${ }^{8}$ Banerjee ${ }^{11}$ reported two cases of irreducible Seymour fractures secondary

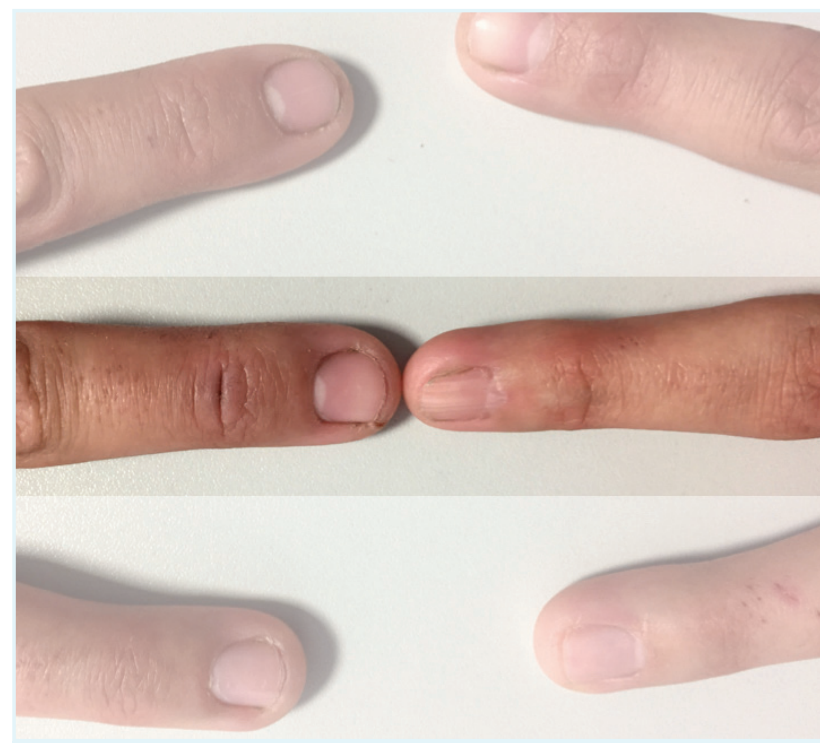

FIGURE 5. Slight nail growth disturbance (narrowing of the growth plate and partial onycholysis accentuated at the radial side).

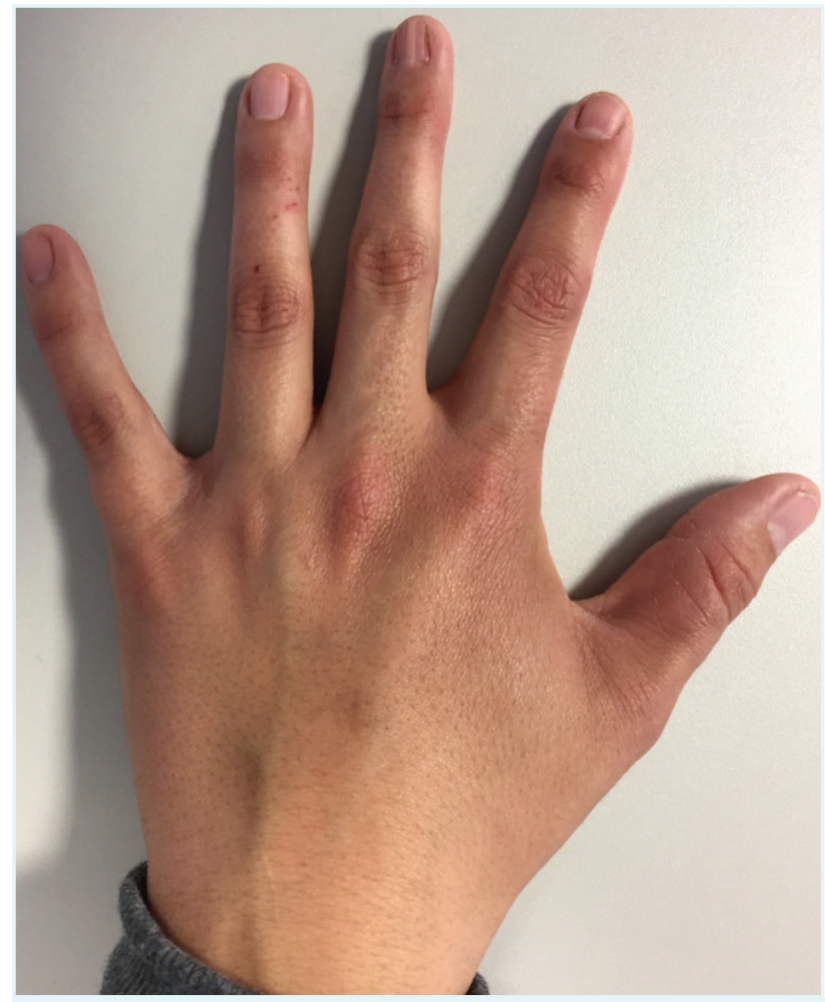

FIGURE 6. Slight rotation of the distal phalanx.

to interposition of a proximally based bucket handle flap of nail fold. Complete reduction was only possible after removal of this interposing flap. The authors consider it an indispensable step to prevent delayed/non-unions, physeal arrest, nail deformity, and chronic osteomyelitis.

The severity of infection associated with open Seymour fractures is frequently brought up in the literature. However, very few studies have specifically described or investigated these cases. ${ }^{7}$ To our knowledge, Reyes and Ho's study 9 is the largest reported cohort of Seymour fractures, and it further demonstrates the importance 
of timely treatment of this injury using open fractures principles to avoid infection. Accordingly to these studies, the authors relate the infection on the presented case mainly to the non-irrigation and debridement prior to closed reduction and K-wire fixation, and no antibiotics prescription.

At the last evaluation, there was also a slight nail growth disturbance and rotation of the distal phalanx. Some authors have reported that nail growth disturbance is caused by injury to the nail bed rather than by different treatment methods. ${ }^{2}$ Rotation of the distal phalanx as a complication, is not described in the literature.

These fractures are often underdiagnosed and untreated - given their benign appearance - and are potentially serious injuries requiring early and adequate treatment, particularly in the case of open fractures. Every patient who presents with a mallet finger deformity, along with an avulsed nail plate should be evaluated radiographically for a Seymour fracture. Conversely, any juxta-articular distal phalanx fracture identified radiographically should be clinically examined for nail plate avulsion or evidence of an open nailbed injury.

It is imperative to recognize these injuries early and treat them appropriately to avoid complications as delayed union/malunion/non-union and infection.

CONFLICTS OF INTEREST: The authors declare that they have no conflicts of interest.

FINANCIAL SUPPORT: This work has not received any contribution, grant or scholarship.

CONFIDENTIALITY OF DATA: The authors declare that they have followed the protocols of their work center on the publication of data from patients.

PROTECTION OF HUMAN AND ANIMAL SUBJECTS: The authors declare that the procedures followed were in accordance with the regulations of the relevant clinical research ethics committee and with those of the Code of Ethics of the World Medical Association (Declaration of Helsinki).

CONFLITOS DE INTERESSE: Os autores declaram não ter qualquer conflito de interesse na realização do presente trabalho.

FONTES DE FINANCIAMENTO: Não houve qualquer fonte de financiamento na realização do presente trabalho.

CONFIDENCIALIDADE DOS DADOS: Os autores declaram ter seguido os protocolos da sua instituição acerca da publicação dos dados de doentes.

PROTEÇÃO DE PESSOAS E ANIMAIS: Os autores declaram que os procedimentos seguidos na elaboração do presente trabalho estão em conformidade com as normas das comissões de investigação clínica e de ética, bem como da declaração de Helsínquia e da Associação Médica Mundial.

\section{LEARNING OBJECTIVES}

- Provide information about the mechanism of injury for Seymour fractures

- Explain the nature of deformity and pathomechanics of Seymour fractures

- Describe the presentation and clinical picture of Seymour fractures

- Discuss the surgical treatment of Seymour fractures

- Review the available literature about the treatment's outcome of Seymour fracture

\section{REFERENCES}

1. Ugurlar M, Saka G, Saglam N, Milcan A, Kurtulmus T, Akpınar F. Distal phalanx fracture in adults: Seymour-type fracture. J Hand Surg. 2013;39:237-41.

2. Krusche-Mandl I, Köttstorfer J, Thalhammer G, Aldrian S, Erhart J, Platzer P. Seymour Fractures: Retrospective Analysis and Therapeutic Considerations. J Hand Surg. 2013;38:25864.

3. Zipoli B, Donon L, Ribeyre D. Surf et fractures de Seymour. Chir Main. 2010;29:263-5.

4. Fischer MD, McElfresh EC. Physeal and periphyseal injuries of the hand. Patterns of injury and results of treatment. Hand Clin. 1994;10:287-301.

5. Abzug J, Kozin S. Seymour Fractures. J Hand Surg. 2013;38:2267-70.

6. Ganayem M, Edelson G. Base of distal phalanx fracture in children. J Pediatr Orthop. 2005;25:487-9.

7. Seymour N. Juxta-epiphyseal fracture of the terminal phalanx of the finger. J Bone Joint Surg Br. 1966;48:347-349.

8. Al-Qattan MM. Extra-articular transverse fractures of the base of the distal phalanx (Seymour's fracture) in children and adults. J Hand Surg Br. 2001;26:201-6.

9. Reyes B, Ho C. The high risk of infection with delayed treatment of open Seymour fractures. J Pediatr Orthop. 2017;37:247-53.

10. Engber W, Clancy W. Traumatic avulsion of the finger nail associated with injury to the phalangeal epiphyseal plate. J Bone Joint Surg. 1978;60:713-4.

11. Banerjee A. Irreducible distal phalangeal epiphyseal injuries. J Hand Surg. 1992;17:337-8. 